\title{
Ренттенендоваскулярні методи в лікуванні шлунково-кишкових кровотеч неварикозної етіології
}

\author{
M. R. BUBNYAK ${ }^{1,2}$, S. L. RACHKEVYCH ${ }^{2}$, YA. A. KOROL ${ }^{1}$
}

Lviv National Medical University by Danylo Halytskyi ${ }^{1}$, Lviv City Municipal Emergency Hospital ${ }^{2}$

\section{ENDOVASCULAR TECHNIQUES IN THE TREATMENT OF NON-VARICEAL GASTRO-INTESTINAL BLEEDINGS}

\begin{abstract}
У статті проаналізовано застосування селективної ангіографії та емболізації лівої шлункової артерії у 6 хворих зі шлунковими кровотечами неварикозної етіології з високим ризиком рецидиву. Завдяки емболізації у всіх пацієнтів вдалося досягти стабільного гемостазу й уникнути ургентної операції з приводу кровотечі, що вказує на ефективність застосування ендоваскулярних методик при шлунково-кишкових кровотечах і дозволяє рекомендувати їх ширше застосування в хірургії.

We analyzed the usefulness of selective angiography and embolization of the left gastric artery in 6 patients with non-variceal gastric bleeding with a high risk of recurrence of hemorrhage. After embolization we achieved stable hemostasis in all patients and prevented urgent surgery for the management of the bleeding, indicating the efficacy of endovascular techniques in the gastro-intestinal bleeding and recommending their wider use in surgery.
\end{abstract}

Лікування гострих шлунково-кишкових кровотеч $є$ важливою і складною проблемою абдомінальної хірургії, насиченою нестандартними і неординарними ситуаціями, яка потребує комплексного підходу i тісної співпраці фахівців різних спеціальностей (міждисциплінарний підхід) для досягнення позитивного і прогнозованого результату.

Частота шлунково-кишкових кровотеч (ШКК) залишається сталою, складаючи 50-172 випадки на 100 тис. жителів на рік, і залежить від економічного розвитку регіону та вікового складу населення. В Україні щорічно госпіталізують у стаціонари близько 50 тис. хворих із ШКК. Найчастішими причинами кровотеч $є$ пептична виразка (57,9 \%), ерозивно-геморагічний гастрит (14 \%), пухлини шлунка (7,5 \%), синдром Маллорі-Вейсса (7 \%), варикозне розширення вен стравоходу і шлунка $(6,4$ \%) $[2,4]$.

Широке впровадження езофагогастродуоденоскопії в клінічну практику дозволяє верифікувати джерело кровотечі при першому дослідженні у 71,2-98 \% хворих із більшою інформативністю та здійснити зупинку кровотечі чи попередити її рецидив. Термічні методи ендоскопічного гемостазу - електрокоагуляція, аргоноплазмова і радіочастотна коагуляція, тепловий зонд ефективні у 96,6-100 \% хворих, а рецидиви кровотечі після них виникають у 4,3-12 \% пацієнтів, i частота їх залежить від типу стигмат кровотечі [2].
Найвищий рівень летальності спостерігається при екстрених операціях внаслідок триваючої кровотечі 27,3 \%, при превентивних операціях (високий ризик рецидиву геморагії) цей показник становить 15,4 \% [3].

Незважаючи на значні досягнення медикаментної терапії та ендоскопічної техніки, летальність при гострих гастродуоденальних кровотечах неварикозної етіології, зокрема при рецидивах кровотеч, залишається незмінною. Тому використання сучасних ендоваскулярних технологій для покращення результатів лікування цієї категорії пацієнтів в Україні стає дедалі актуальнішим $[1,5]$.

Мета роботи: визначити доцільність і лікувальні можливості селективної ангіографії та ендоваскулярної емболізації у пацієнтів із шлунковими кровотечами з високим ризиком рецидиву.

Ангіографію та емболізацію судини - джерела кровотечі застосовуємо з 2010 р. на агіографічному комплексі “Siemens Axiom Artis dMP". Загалом проведено 47 емболізацій селезінкової та лівої шлункової артерій при портальній гіпертензії і кровотечах 3 варикозно розширених вен стравоходу та шлунка, 7 емболізацій при кровотечах на грунті патології підшлункової залози, 1 - при внутрішньочеревній кровотечі нез'ясованої етіології.

За період 2010-2015 рр. ургентну ангіографію з емболізацією лівої шлункової артерії проведено 6 
пацієнтам зі шлунковими кровотечами неварикозної етіології, в яких, за даними ендоскопії, виявлено високий ризик рецидиву геморагії. Серед пацієнтів було 3 жінки і 3 чоловіки, віком від 58 до 89 років. Троє пацієнтів доставлено ургентно бригадами ШМД із клінікою шлунково-кишкової кровотечі, у 4-го хворого кровотеча виникла у стаціонарі на 13-ту добу після ургентної операції з приводу гострої кишкової непрохідності, ускладненої неспроможністю швів анастомозу і кишковою норицею, у 5-ї - на фоні гострого порушення мозкового кровообігу за ішемічним типом, у 6-го - при підготовці до операційного втручання з приводу пухлини лівої нирки. У 4 пацієнтів при ФЕГДС виявлено виразковий дефект шлунка розмірами 2-6 см, з фіксованим тромбом (Forrest-Ill), у 2-x - підтікання крові з-під тромбу (Forrest-Ic), у 2-х - виразку 2 і 4 см у діаметрі з тромбованою судиною (Forrest-IIa). Патогістологічне дослідження біопсійного матеріалу в 2-х пацієнтів виявило пухлину шлунка. Клінічно стан усіх пацієнтів був тяжким: виражена постгеморагічна анемія (рівень гемоглобіну - 40-80 г/л), декомпенсована супровідна патологія, загальне виснаження, похилий та старечий вік. Відповідно, ризик ургентного відкритого операційного втручання визначено високим. При виконанні селективної ангіографії (рис. 1) у 3-х пацієнтів було виявлено екстравазацію контрастної речовини за межі судинного русла (триваюча кровотеча), в інших 3-х - непрямі ознаки кровотечі (обрив контрастованої судини, різкий перепад її діаметра). В одному випадку емболізацію проведено розчином етанолу, у 4-х - пінополіуретановими емболами та в 1-му - мік-

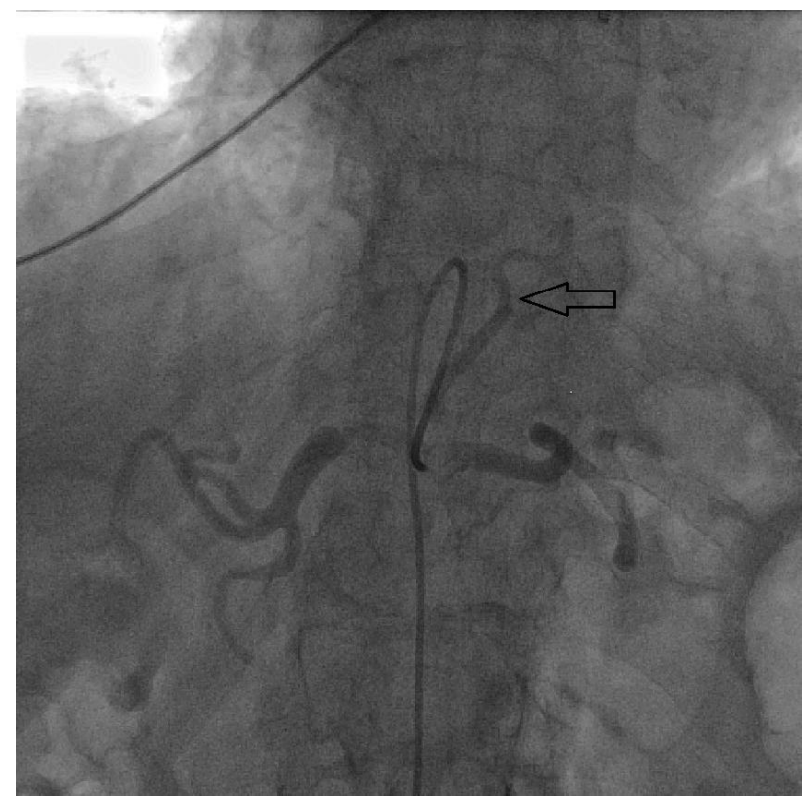

Рис. 1. Селективна ангіографія черевного стовбура 3 крупною лівою шлунковою артерією (стрілка).

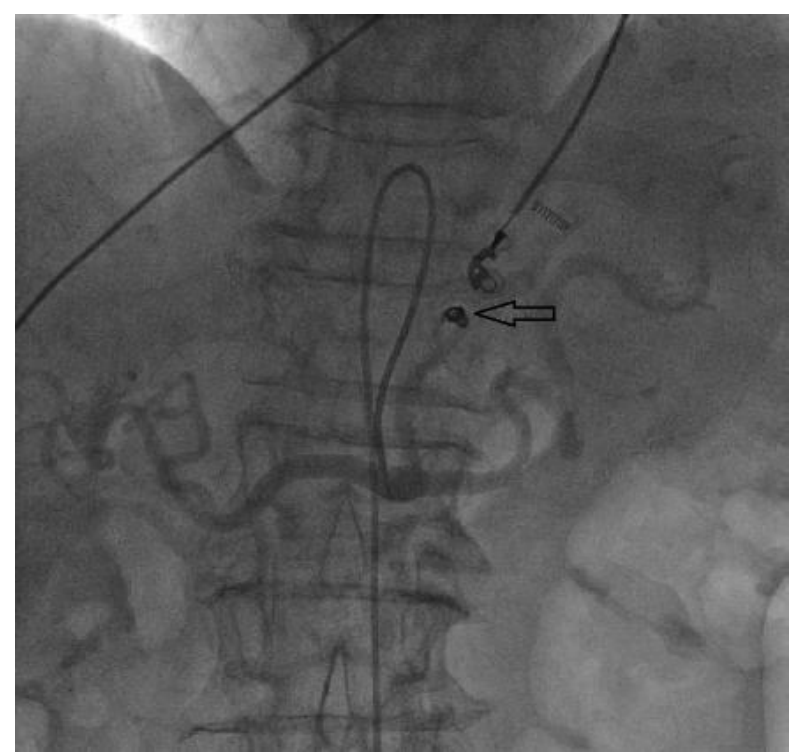

Рис. 2. Ангіографія черевного стовбура після емболізації ЛША мікроспіраллю (стрілка).

роспіраллю (рис. 2). В усіх хворих досягнуто значної редукції кровотоку по лівій шлунковій артерії.

Після проведення емболізації рецидивів кровотечі не було в жодному випадку. При ФЕГДС через 1-2 доби у 5 пацієнтів виявлено виразковий дефект із сірим дном (Forrest III), у 1-го - 3 мікротромбами у кратері (Forrest IIc). Відтак, жодного з пацієнтів не оперовано з приводу кровотечі. У подальшому усім хворим проведено курс консервативної терапії i 4-х 3 них виписано зі стаціонару в термін 10-16 днів після емболізації у задовільному стані. 3 причин, не пов'язаних з кровотечею, а від основного захворювання, померли двоє хворих: одна - на 3-тю добу після емболізації від наслідків ГПМК, інший - на 13-ту добу після емболізації від поліорганної недостатності на грунті розпаду пухлини лівої нирки з проростанням у підшлункову залозу і селезінку 3 формуванням абсцесу заочеревинного простору i перитоніту. Пацієнтам з пухлинами рекомендовано планове операційне лікування.

Висновки. 1. Селективна ангіографія дає можливість виявити прямі або непрямі ознаки судини джерела кровотечі.

2. Емболізація судини-мішені, особливо у пацієнтів високого ризику, в яких не вдається досягти стабільного гемостазу ендоскопічними методами, дає змогу стабілізувати його та запобігти рецидиву кровотечі.

3. Використання ендоваскулярного гемостазу дозволяє уникнути відкритої операції або відтермінувати іï та провести в плановому порядку, при компенсованому стані пацієнта, і тим самим покращити результат лікування. 


\section{ПОВІДОМЛЕННЯ}

\section{СПИСОК ЛІТЕРАТУРИ}

1. Ендоскопічний гемостаз при гострокровоточивих злоякісних пухлинах шлунка / П. Д. Фомін, П. В. Іванчов, I. I. Лемко, О. В. Ігнатов // Науковий вісник Ужгородського університету. - 2010. - Вип. 39. - С. 160-165. - (Серія “Медицина”).

2. Фомин П. Д. Кровотечения из верхних отделов желудочнокишечного тракта: причины, факторы риска, диагностика, лечение / П. Д. Фомин, В. И. Никишаев // Здоров’я України, 2010.

3. Тактика і перспективи лікування хворих з виразковими гастродуоденальними кровотечами / В. А. Шуляренко, Я. П. Фелештинський, В. І. Мамчич [та ін.] // Хірургія України. - 2012. - № 2. - С. 30-34.

4. Кондратенко П. Г. Острое кровотечение в просвет органов пищеварительного канала / П. Г. Кондратенко, Н. Л. Смирнов, Е. Е. Раденко. - Донецьк, 2006.

5. Ангіографічна емболізаціяпри гастродуоденальній кровотечі. Безпечність, ефективність та предиктори успіху / G. A. Roultsides, C. J. Kim, R. Orlando [et al.] // Медичний реферативний журнал. - 2009. - № 1-4. - С. 103.

Отримано 03.03.15 